\title{
ROUGHNESS AND COLOR EVALUATION OF WOOD POLYMER COMPOSITES FILLED BY HOUSEHOLD WASTE OF MATE-TEA
}

\author{
Pedro H. G. de Cademartori ${ }^{1}$, André L. Missio ${ }^{2}$, Bruno D. Mattos ${ }^{3}$, Darci A. Gatto ${ }^{2,4, \text {, }}$ \\ Washington L. E. Magalhães ${ }^{3,5}$, Edson A. Lima ${ }^{5}$
}

\begin{abstract}
This study presents the preparation of polypropylene composites filled with mixtures of household waste of mate-tea and wood particles to increase the economic value chain of mate-tea, especially in Latin America. Filler mixtures in proportions ranging from 0 to $60 \%$ depending on the type of particle were used. The polypropylene matrix was fixed at $40 \%$ and roughness surface and color evaluation were performed. The highest mean roughness ( $\mathrm{Ra}$ ) was observed for the composite with 30:30\% proportion of filler mixture, which denotes the difficulty of homogenizing a mixture of fillers with different shapes and dimensions. Nevertheless, even with higher roughness for composites with a balanced blend of filler, this does not imply the presence of large peaks and valleys. In general, all the composites presented a dark color. Variation of color composites was more evident for higher proportions of household waste of mate-tea.
\end{abstract}

Keywords: Aesthetic characteristics, economic value chain, eucalypt wood, Ilex paraguariensis, polypropylene composite.

\section{INTRODUCTION}

In the last few years, research on the development of new composite materials have been based on the use of lignocellulosic materials, mainly due to their easy reutilization and recycling (Haque et al. 2009, Ashori and Nourbakhsh 2010, Binhussaina and El-Tonsy 2013, Magalhães et al. 2013). Mengeloglu and Karakuş (2008) reported that polymeric composites usually contain organic filler such as agricultural residues, wood of different species and many types of polymers (polyethylene, polyvinyl chloride and polypropylene). In this context, the use of lignocellulosic materials as a filler shows many advantages for the production of polymeric composites, such as low density, low energy consumption, low abrasion, multi-functionality, low cost and use of renewable materials (Kazayawoko et al. 1999, Clemons 2002, Abu-Sharkh et al. 2004, Tserki et al. 2005).

Amongst lignocellulosic materials, two of them are widely available for use as reinforcement or filler of polymeric matrices: mate-tea particles and wood particles from fast-growing eucalypt species. Mate-tea is originated from extractive activities of Ilex paraguariensis trees and their residues come from household disposal in countries such as Argentina, Uruguay and Brazil - the latter mainly in the Southern region -, which use mate-tea for the tea consumption. According to Pagliosa et al. (2010), per capita consumption of mate-tea is $\sim 5-7 \mathrm{~kg} \mathrm{yr}^{-1}$ both in Argentina and Uruguay and $\sim 1,2 \mathrm{~kg} \mathrm{yr}^{-1}$ in Brazil, producing $\sim 481000$ tons of residues per year. Reutilization of these residues is very important, especially in products that accept lignocellulosic materials in their composition, such as polymeric composites.

\footnotetext{
${ }^{1}$ Wood and Forestry Science Center (PPGEF). Federal University of Paraná, Curitiba, Brazil

${ }^{2}$ Forestry Engineering (PPGEF), Forest Products Laboratory, Center for Rural Sciences, Federal University of Santa Maria, Santa Maria, Brazil

${ }^{3}$ College of Materials Science \& Engineering (PIPE), ${ }^{2}$ Federal University of Paraná, Polytechnic Center, Curitiba, Brazil.

${ }^{4}$ Faculty of Materials Engineering (PPGCEM), Federal University of Pelotas, Pelotas, Brazil.

${ }^{5}$ Embrapa Forestry, PR, Colombo, Brazil.

- Corresponding author : darcigatto@pq.cnpq.br

Received: 01.03.2014 Accepted: 15.09.2014
} 
On the other hand, as wood residues from fast-growing species are highly appreciated, they have gained a major share of the world market. According to Ayrilmis and Kaymakci (2013), wood flour typically costs about $\sim 0,18-0,36 \mathrm{U} \$ \mathrm{~kg}^{-1}$, which makes their use as reinforcement or filler of polymeric materials feasible in order to reduce the final cost of production. Moreover, the use of wood particles could be a solution to obtain specific properties according to the desired characteristics of the products.

As reported by Magalhães et al. (2013), Darabi et al. (2012), and Jeamtrakull et al. (2012), lignocellulosic residues are used jointly with polymeric matrices (for example, PP, PE and HDPE) for the production of composite materials. Therefore, the development of research for the use of materials from natural sources as reinforcement or filler of polymeric composites without significant influence on their properties when in service is indispensable.

Aesthetic purposes are widely appreciable in applications of wood-polymer composites when that material is used for production of decks, fences, and baseboards, for example. The main characterization for aesthetic purposes is the colorimetry. This technique has been extensively used through CIE method (Commission International de L'Éclairage), where in some parameters are measured: lightness $\left(L^{*}\right)$, chromatic coordinates $\left(a^{*}\right.$ and $\left.b^{*}\right)$, chroma $\left(C^{*}\right)$ and hue angle $(h)$ (Cademartori et al. 2014, Cademartori et al. 2013, Dubey et al. 2012).

Other important characteristic in the composites for aesthetic purposes is the surface roughness. Measurement of roughness is usually performed through Ra (roughness average), Ry (maximum roughness) and Rz (mean peak-to-valley height) parameters, which infer level of texture and necessity of finishing process of the composites. Furthermore, roughness is able to influence the capacity of bonding of determined materials (Jarusombuti and Ayrilmis 2011, Kaymacki et al. 2013).

The present study aimed to incorporate particles of household waste of mate-tea in flat-pressed WPCs produced from eucalypt particles of Eucalyptus benthamii fast-growing specie in a matrix of polypropylene (PP), and characterize their roughness and color appearance. 


\section{MATERIALS AND METHODS}

\section{Raw Material}

Particles of household waste of mate-tea were collected in Paraná State, Southern Brazil, and eucalypt wood chips (Eucalyptus benthamii) were collected from waste of a sawing process in Embrapa Forestry sawmill (Figure 1). This material presented moisture content $\sim 70 \%$ on wet weight basis and was dried in an oven at $65 \pm 2^{\circ} \mathrm{C}$ to obtain constant weight. Subsequently, the material was cut into small particles using a Wiley knife mill (40-60 mesh).

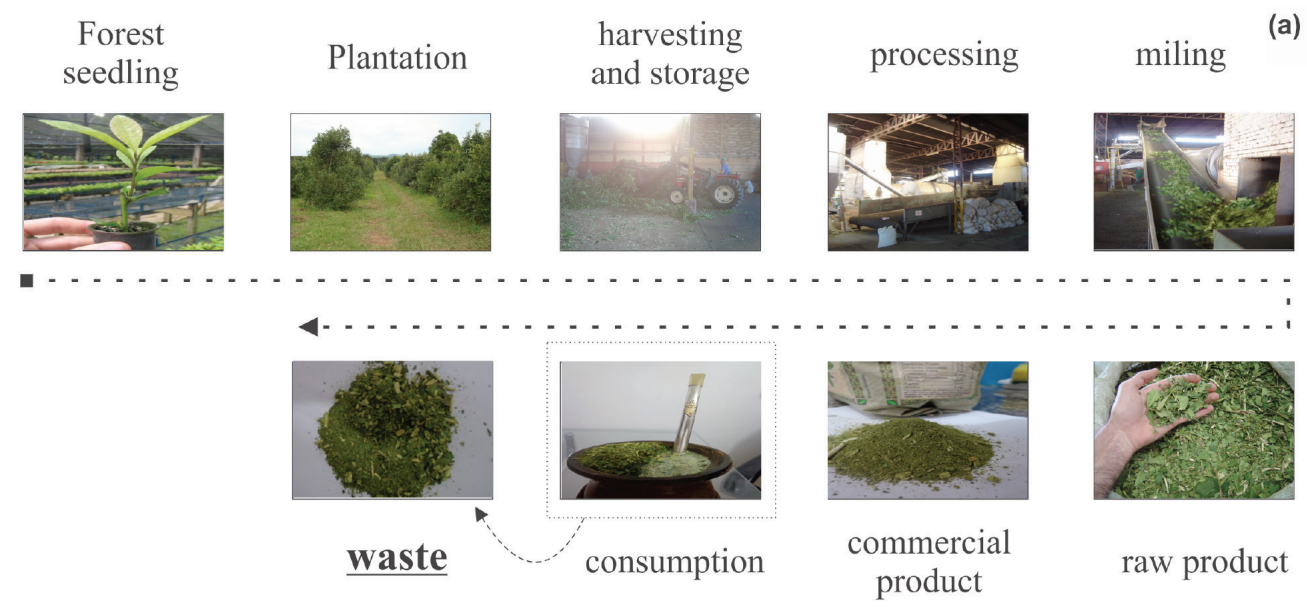

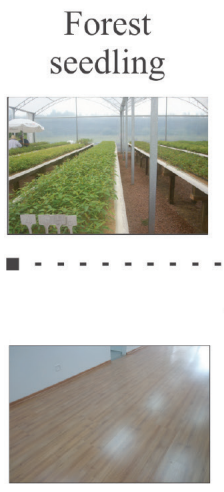

applications

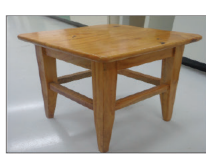

products

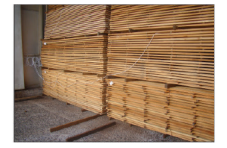

boards

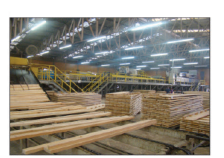

2nd

processing
1 st processing
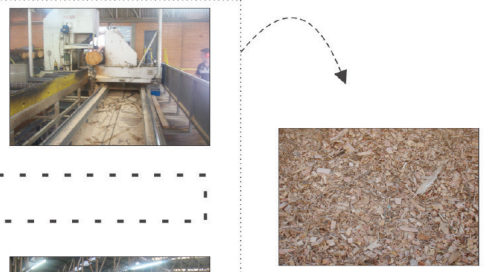

waste

Figure 1. Schematic of waste generation and obtainment process of mate-tea (a) and wood (b).

Matrix of polypropylene - PP H103 supplied by Braskem (Brazil) with density of $905 \mathrm{~kg} \mathrm{~m}^{-3}$ and melt flow index of $40 \mathrm{~g} 10 \mathrm{~min}^{-1}$ was used. The number-average molecular weight $\left(\mathrm{M}_{\mathrm{n}}\right)$ of PP is 49,44 and the mean molecular weight $\left(\mathrm{M}_{\mathrm{w}}\right)$ is 235597 . 


\section{Preparation of composites}

The particles of mate-tea household waste and eucalypt wood measuring 40-60 mesh were manually mixed in different concentrations of particles: matrix (total weight of $80 \mathrm{~g}$ ) according to table 1.

Table 1. Composition of the studied formulations.

\begin{tabular}{|c|c|c|c|c|c|c|c|c|c|c|c|}
\hline \multirow{2}{*}{ Components (w/w\%) } & \multicolumn{11}{|c|}{ Composite type } \\
\hline & $\mathrm{A}$ & B & $\mathrm{C}$ & $\mathrm{D}$ & $\mathrm{E}$ & $\mathrm{F}$ & $\mathrm{G}$ & $\mathrm{H}$ & I & $\mathrm{J}$ & $\mathrm{L}$ \\
\hline Household waste & 60 & 54 & 48 & 42 & 36 & 30 & 24 & 18 & 12 & 6 & 0 \\
\hline Eucalypt wood & 0 & 6 & 12 & 18 & 24 & 30 & 36 & 42 & 48 & 54 & 60 \\
\hline PP-matrix & 40 & 40 & 40 & 40 & 40 & 40 & 40 & 40 & 40 & 40 & 40 \\
\hline
\end{tabular}

The composites were molded using a Marconi MA098/A electrically heated hydraulic press with homogenous distribution of pressure. The molding process was carried out at $175 \pm 2^{\circ} \mathrm{C}$ for 20 minutes with a pressure of $4 \mathrm{MPa}$. Direct contact between the polypropylene powder and metal platens during the heating and pressing process occurred using wax paper.

The nominal size of the composites was $140 \mathrm{~mm}$ x $140 \mathrm{~mm} \times 4 \mathrm{~mm}$ after the cooling process. Additives and coupling agents were not used in the molding process of the composites.

\section{Surface roughness}

A study of surface roughness of the composites was carried out using a Surface Roughness Measuring Instrument - SE 1200 of trademark Kosaka Lab - Surfcorder. Vertical resolution of the equipment is $0,0064 \mu \mathrm{m}$ and vertical magnitude (V) is $100 \mu \mathrm{m}$. The length of evaluation $(\lambda \mathrm{c})$ was adjusted to $2,5 \mathrm{~mm}$ (extra measure of $4 \mathrm{x}$ ) and the velocity measure to $0,5 \mathrm{~mm} \mathrm{~s}^{-1}$.

The measured parameters were Ra, Ry and Rz (roughness average, maximum roughness and mean peak-to-valley height, respectively) according to the ISO 4287 standard. Four samples of $2 \times 2 \mathrm{~cm}$ cut from each composite were used, in which the measurements were performed in triplicate at different points of the sample. The border was avoided to prevent influence of machining on the measurements.

Surface microstructure of composites A, F and L was qualitatively analyzed. To achieve this, a Metallizer Quick Coater (model SC-701 brand Sanyu Electron) was used to coat the samples with a thin layer of gold, whereas the microscopic images were captured using a Scanning Electron Microscope (model 550 from brand Shimadzu SSX).

\section{Color evaluation}

Colorimetric evaluation was performed using a Konica Minolta colorimeter configured for using D65 light source and observation angle of $2^{\circ}\left(\mathrm{CIE}-L^{*} a^{*} b^{*}\right)$. Twelve measurements of colorimetric parameters $L^{*}$ (lightness), $a^{*}$ (red-green chromatic coordinate) and $b^{*}$ (blue-yellow chromatic coordinate) were performed for each composite. 
The Chroma $\left(C^{*}\right)$, hue angle $(h)$ and the parameters of $\Delta \mathrm{E}, \Delta \mathrm{L}^{*}, \Delta \mathrm{a}^{*}$ and $\Delta \mathrm{b}^{*}$ were calculated using equations 1 to 6 , respectively.

$$
\begin{gathered}
C^{*}=\left(a^{*^{2}}+b^{*^{2}}\right)^{1 / 2} \\
h=\operatorname{tang}^{-1}\left(b^{* / a} a^{*}\right) \\
\Delta \mathrm{E}=\left(\Delta L^{*^{2}}+\Delta a^{*^{2}}+\Delta b^{*^{2}}\right)^{1 / 2} \\
\Delta L^{*}=L_{\mathrm{t}}^{*}-L^{*}{ }_{\mathrm{nt}} \\
\Delta a^{*}=a^{*}-a^{*}{ }_{\mathrm{nt}} \\
\Delta b^{*}=b^{*}-b^{*}{ }_{\mathrm{nt}}
\end{gathered}
$$

\section{Data analysis}

The distribution and variance data were evaluated. In the case of normal distribution and homogeneous variance results, interpretation of the data was performed by analysis of variance (ANOVA) at 1 and $5 \%$ probability of error. In the case of rejection of the null hypothesis ( $<<0,01$ or $p<0,05)$, Fisher LSD test was performed to group the properties by types of composites. 


\section{RESULTS AND DISCUSSION}

\section{Surface roughness}

The maximum values of Ra were observed for composites $\mathrm{E}, \mathrm{F}$ and $\mathrm{G}$, which were statistically equal by Fisher's LSD test $(p<0,001)$. Similar results for Ry and Rz were also observed. However, composite F showed statistically higher mean values than the values found in all other composites (Figure 2).

Predominance of only one type of filler in the composites significantly decreased the surface roughness. This suggests it is very difficult to obtain full homogenization between two fillers with different shapes and dimensions (Figure 1), wherein waste of mate-tea is spherical and irregular, and eucalypt particles are mostly flattened and elongated. In the same context, Akbulut et al. 2000, affirmed that the particle size and geometry are major factors that play a significant role in surface roughness of wood based composites.
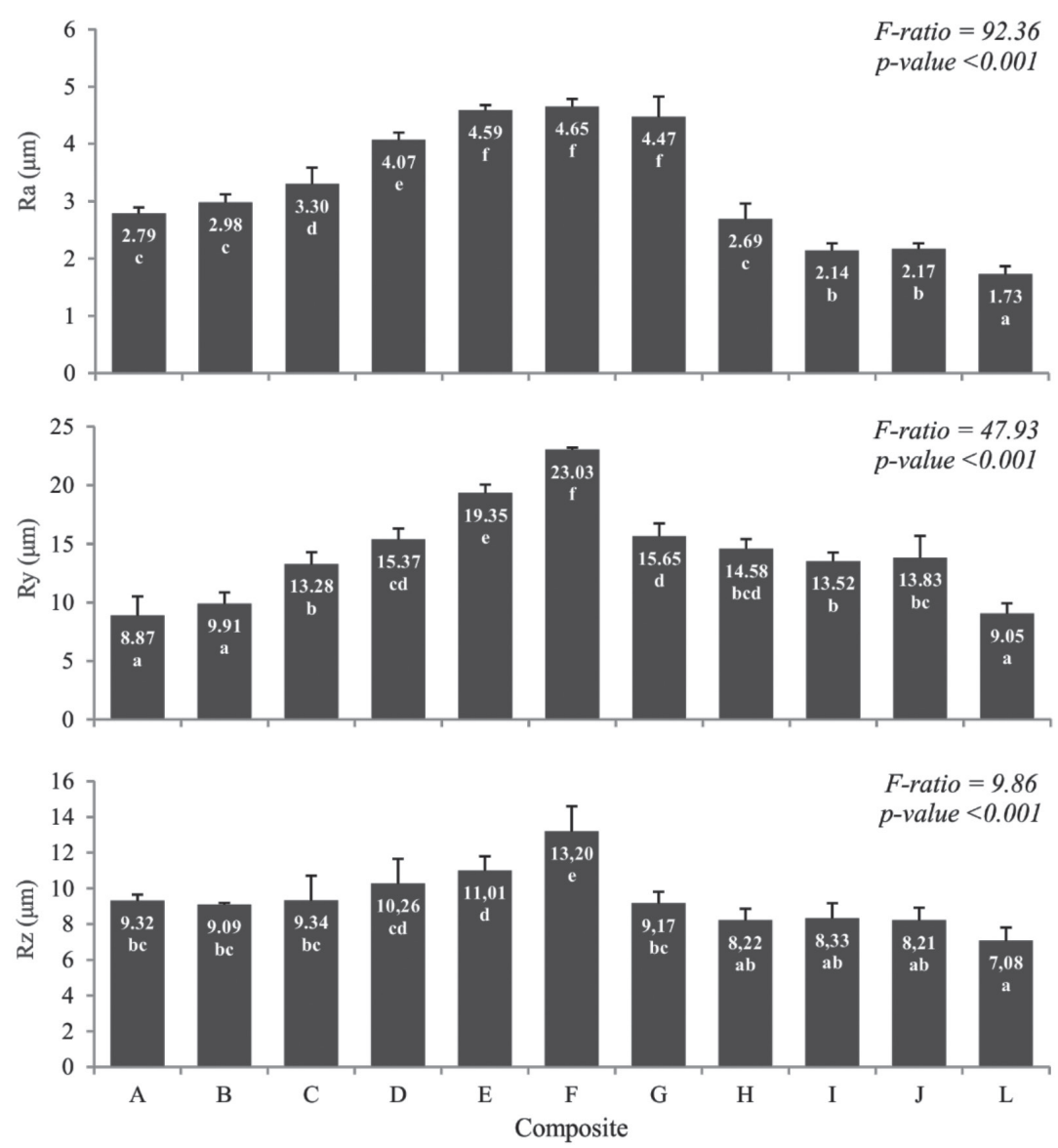

Figure 2. Surface roughness of composites.

Parameter Ra of composites A, B, C and D (with a high proportion of mate-tea waste) was statistically higher than the value found for composites H, I, J and L (with a high proportion of eucalypt particles), in which - as can be seen in the SEM images (Figure 3) - the smoothest surface was observed for composite $\mathrm{L}(1,73 \mu \mathrm{m})$, 


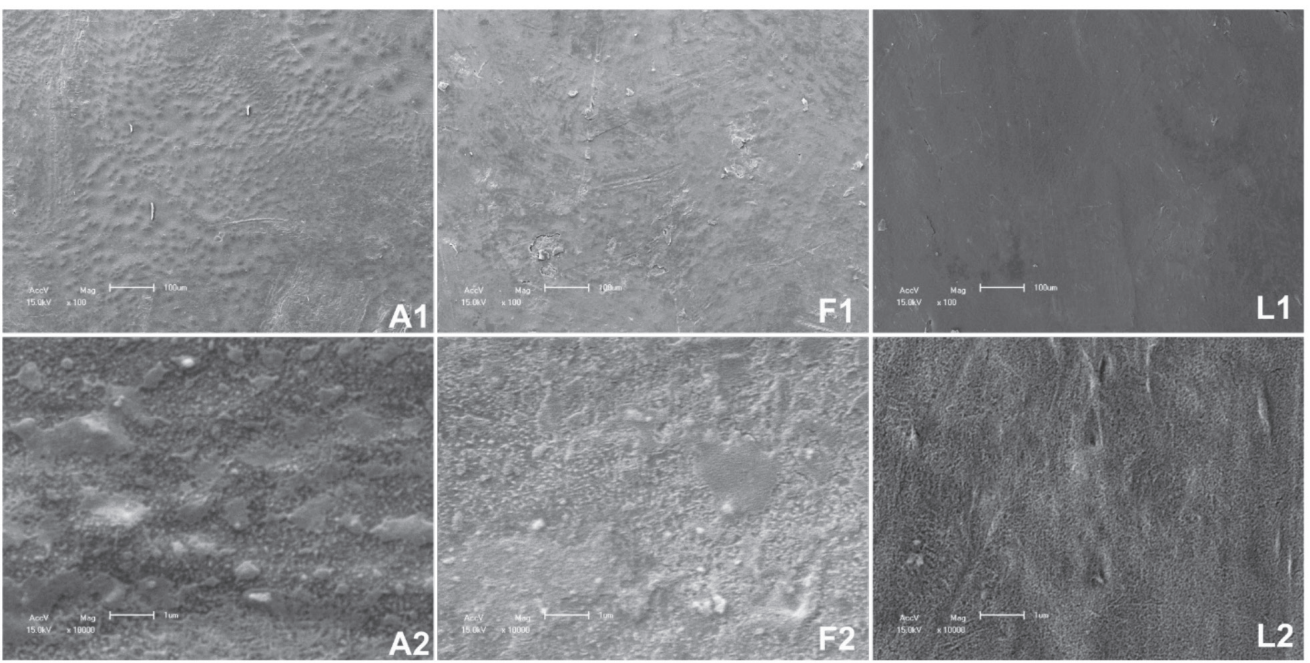

Figure 3. SEM micrographs of the A, F and L composites surface.

Parameter Rz is very important to complement Ra because Ra dilutes the maximum peak value at a mean. The lowest values of Ry were observed for composites A, B and L, wherein the maximum peaks were 8,$87 ; 9,91$ and $9,05 \mu \mathrm{m}$, respectively.

The lowest values of Ry (maximum roughness) were observed for the composites produced only with one type of filler or a high proportion of only one, i.e., these composites tend to have better dispersion of the filler and more homogeneous particle size and shape.

The results of Ra are slightly higher than those observed by other authors for WPC and wood panels (Darabi et al. 2012, Ayrilmis 2011, Jarusombuti and Ayrilmis 2011, Ayrilmis et al. 2012, Akgül et al. 2012), while Ry and Rz values are lower than those found in most of these aforementioned studies. Ry and Rz remained between 8,87-23,02 $\mu \mathrm{m}$ and 7,08 -13,20 $\mu \mathrm{m}$, respectively, which shows that flatpressed composites produced in this study present a homogenous surface roughness and an absence of large valley or peaks along the material's surface. The behavior of surface roughness was attributed to the type of particles (household waste of mate-tea or eucalypt wood) and to the homogenization process of this material before production of the composite.

\section{Color evaluation}

Color of the composites, which are used as fences, decks and other decorative elements, is an important parameter to be measured. Figure 4 presents a visual aspect of color of composites A, F and L. Clear visual difference on color of the composites is observed, mainly for composite $\mathrm{F}$. This color difference could be attributed to the mixture of two different types of raw material, which was previously identified in surface roughness analysis.
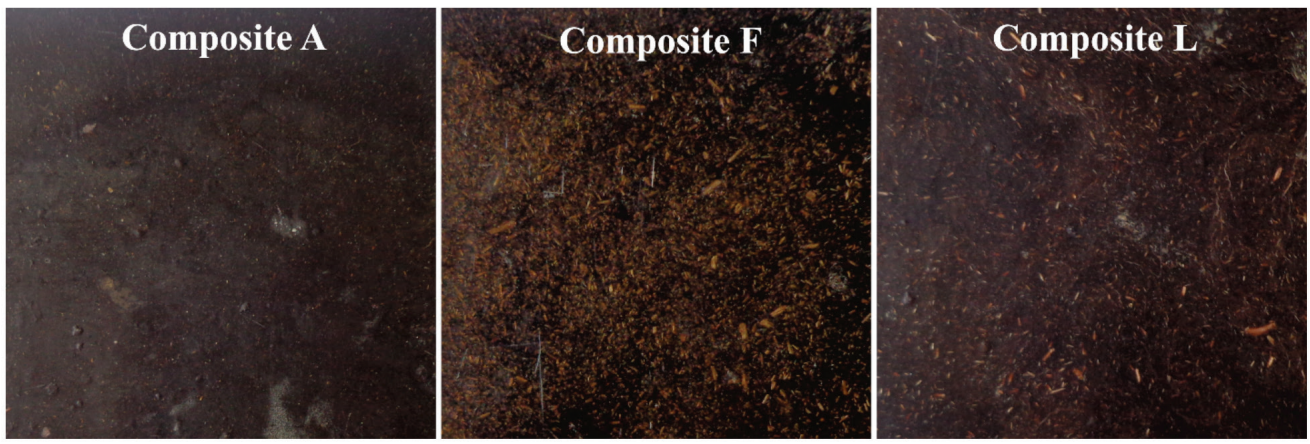

Figure 4. Visual aspect of color of composites A, F and L. 
Table 2 shows the mean values of colorimetric parameters $L^{*}, a^{*}, b^{*}, C^{*}$ and $h$. The parameter $L^{*}$ (lightness) shows that any percentage of particles of household waste of mate-tea tends to darken the color of this material (Table 2). The results varied from 27,52 to 43,03 and the highest value was found in composite L, which was produced only with eucalypt particles. This result is associated to the particles' color, in which eucalypt particles are naturally lighter than household waste of mate-tea particles.

Table 2. Color measurements of the flat pressed composite made with waste mate-tea and eucalypt chips.

\begin{tabular}{|c|c|c|c|c|c|}
\hline Composite & $L^{*}$ & $a^{*}$ & $b^{*}$ & $C^{*}$ & $h^{*}$ \\
\hline A & $\begin{array}{c}30,22 \mathrm{ab} \\
(2,38)\end{array}$ & $\begin{array}{l}2,33 \mathrm{a} \\
(0,37)\end{array}$ & $\begin{array}{c}7,08 \mathrm{ab} \\
(0,93)\end{array}$ & $\begin{array}{l}7,46 \mathrm{a} \\
(0,93)\end{array}$ & $\begin{array}{l}71,72 \mathrm{~d} \\
(2,76)\end{array}$ \\
\hline B & $\begin{array}{c}29,58 \mathrm{ab} \\
(0,34)\end{array}$ & $\begin{array}{c}3,55 \mathrm{abc} \\
(0,02)\end{array}$ & $\begin{array}{l}5,60 \mathrm{a} \\
(0,74)\end{array}$ & $\begin{array}{l}6,64 \mathrm{a} \\
(0,62)\end{array}$ & $\begin{array}{c}57,41 \mathrm{ab} \\
(3,42)\end{array}$ \\
\hline $\mathrm{C}$ & $\begin{array}{c}29,58 \mathrm{ab} \\
(2,57)\end{array}$ & $\begin{array}{c}3,06 \mathrm{ab} \\
(0,75)\end{array}$ & $\begin{array}{c}7,10 \mathrm{ab} \\
(2,44)\end{array}$ & $\begin{array}{l}7,73 \mathrm{a} \\
(2,53)\end{array}$ & $\begin{array}{c}66,25 \mathrm{~cd} \\
(1,88)\end{array}$ \\
\hline $\mathrm{D}$ & $\begin{array}{c}27,52 \mathrm{a} \\
(0,64)\end{array}$ & $\begin{array}{l}2,41 \mathrm{a} \\
(0,38)\end{array}$ & $\begin{array}{l}5,99 \mathrm{a} \\
(1,31)\end{array}$ & $\begin{array}{l}6,48 \mathrm{a} \\
(1,21)\end{array}$ & $\begin{array}{c}67,59 \mathrm{~cd} \\
(5,30)\end{array}$ \\
\hline $\mathrm{E}$ & $\begin{array}{c}30,31 \mathrm{ab} \\
(3,40)\end{array}$ & $\begin{array}{c}2,94 \mathrm{ab} \\
(0,19)\end{array}$ & $\begin{array}{c}7,35 \mathrm{ab} \\
(2,84)\end{array}$ & $\begin{array}{l}7,97 \text { a } \\
(2,63)\end{array}$ & $\begin{array}{c}66,25 \mathrm{~cd} \\
(8,73)\end{array}$ \\
\hline $\mathrm{F}$ & $\begin{array}{c}30,98 \mathrm{ab} \\
(1,07)\end{array}$ & $\begin{array}{c}4,28 \mathrm{bcd} \\
(0,47)\end{array}$ & $\begin{array}{c}7,06 \mathrm{ab} \\
(1,27)\end{array}$ & $\begin{array}{l}8,27 \mathrm{a} \\
(1,28)\end{array}$ & $\begin{array}{c}58,56 \mathrm{ab} \\
(2,94)\end{array}$ \\
\hline G & $\begin{array}{c}30,61 \mathrm{ab} \\
(4,22)\end{array}$ & $\begin{array}{c}4,95 \mathrm{~cd} \\
(2,10)\end{array}$ & $\begin{array}{c}8,56 \mathrm{ab} \\
(4,45)\end{array}$ & $\begin{array}{c}9,89 \mathrm{ab} \\
(4,90)\end{array}$ & $\begin{array}{c}58,90 \mathrm{ab} \\
(3,22)\end{array}$ \\
\hline $\mathrm{H}$ & $\begin{array}{c}34,85 \mathrm{~b} \\
(2,57)\end{array}$ & $\begin{array}{l}5,80 \mathrm{~d} \\
(0,94)\end{array}$ & $\begin{array}{c}11,21 b c \\
(2,10)\end{array}$ & $\begin{array}{c}12,63 \mathrm{~b} \\
(2,27)\end{array}$ & $\begin{array}{c}62,53 \mathrm{bc} \\
(1,69)\end{array}$ \\
\hline I & $\begin{array}{c}32,10 \mathrm{ab} \\
(3,89)\end{array}$ & $\begin{array}{l}5,53 \mathrm{~d} \\
(1,77)\end{array}$ & $\begin{array}{c}8,39 \mathrm{ab} \\
(2,73)\end{array}$ & $\begin{array}{c}10,05 \mathrm{~b} \\
(3,24)\end{array}$ & $\begin{array}{c}56,56 \mathrm{ab} \\
(1,49)\end{array}$ \\
\hline $\mathrm{J}$ & $\begin{array}{c}34,16 \mathrm{~b} \\
(2,44)\end{array}$ & $\begin{array}{l}7,56 \mathrm{e} \\
(0,20)\end{array}$ & $\begin{array}{c}10,47 \mathrm{bc} \\
(1,48)\end{array}$ & $\begin{array}{c}12,93 \mathrm{~b} \\
(1,28)\end{array}$ & $\begin{array}{c}53,94 \mathrm{a} \\
(3,45)\end{array}$ \\
\hline L (Reference) & $\begin{array}{c}43,03 \mathrm{c} \\
(6,83)\end{array}$ & $\begin{array}{c}10,68 \mathrm{f} \\
(0,95)\end{array}$ & $\begin{array}{c}14,41 \mathrm{~b} \\
(3,74)\end{array}$ & $\begin{array}{c}17,98 \mathrm{c} \\
(3,58)\end{array}$ & $\begin{array}{c}52,85 \mathrm{a} \\
(4,46)\end{array}$ \\
\hline F-ratio & $4,91 * *$ & $20,13^{* *}$ & $3,38 * *$ & $5,55^{* *}$ & $6,75^{* *}$ \\
\hline
\end{tabular}

** Significant at $1 \%$ of error

As expected, red-green chromatic coordinate $\left(a^{*}\right)$ values gradually increased with increasing percentage of eucalypt particles because the higher the values of $a^{*}$, the higher is the red tones. On the other hand, the lower the values of $a^{*}$, the higher is the green tones, which is the natural color of particles used in this study (Figure 1). Blue-yellow chromatic coordinate $\left(b^{*}\right)$ showed the same behavior of $a^{*}$ as a function of percentage of eucalypt particles. 
$\Delta \mathrm{E}, \Delta \mathrm{L}^{*}, \Delta \mathrm{a}^{*}$ and $\Delta \mathrm{b}^{*}$ parameters were evaluated as a function of insertion of particles of household waste of mate-tea, wherein the reference was the composite L (made only with eucalypt particles). In summary, $L^{*}$ is the most affected parameter by the insertion of household waste of mate-tea particles (Figure 5). All the parameters of color variation remained constant from composite A to composite $\mathrm{F}$. However, the lower is the proportion of household waste of mate-tea particles, the lower is the color variation.

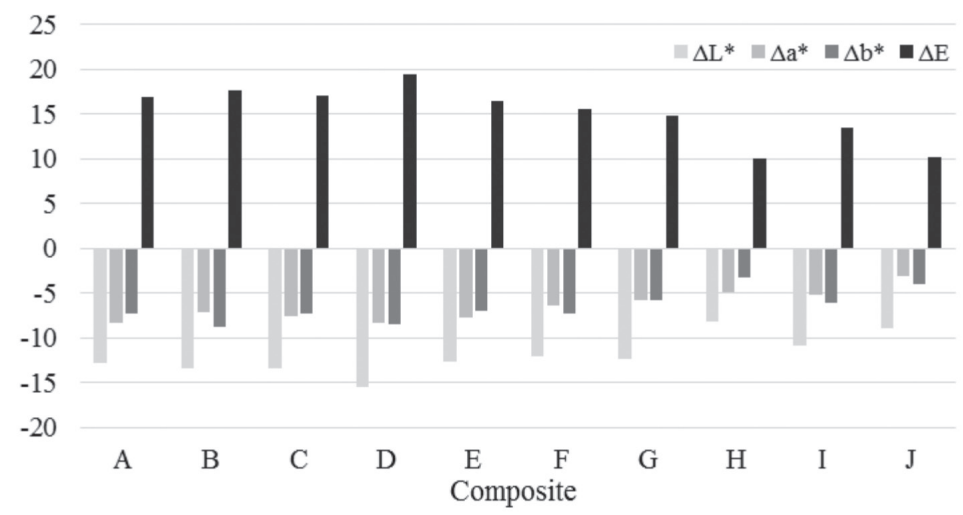

Figure 5. Parameters of color variation.

The mean results of chroma $\left(C^{*}\right)$ and hue angle $\left(h^{*}\right)$ showed that saturation increased with increasing eucalypt particles, whereas $h^{*}$ decreased with increasing eucalypt particles. The effect of eucalypt particles in the composite with higher proportions of household waste of mate-tea is greater than the effect of household waste of mate-tea in the composite with higher proportions of eucalypt particles when $h^{*}$ value of composites A and L (without filler mixture) are compared to $h^{*}$ value of composite $\mathrm{F}$ (the same percentage of both fillers).

Variation of $h^{*}$ mean values between composites A and $\mathrm{F}$ are higher than those found between composites $\mathrm{F}$ and $\mathrm{G}$, which can be visualized through the position of these composites in the diagram of hue angle (Figure 6).
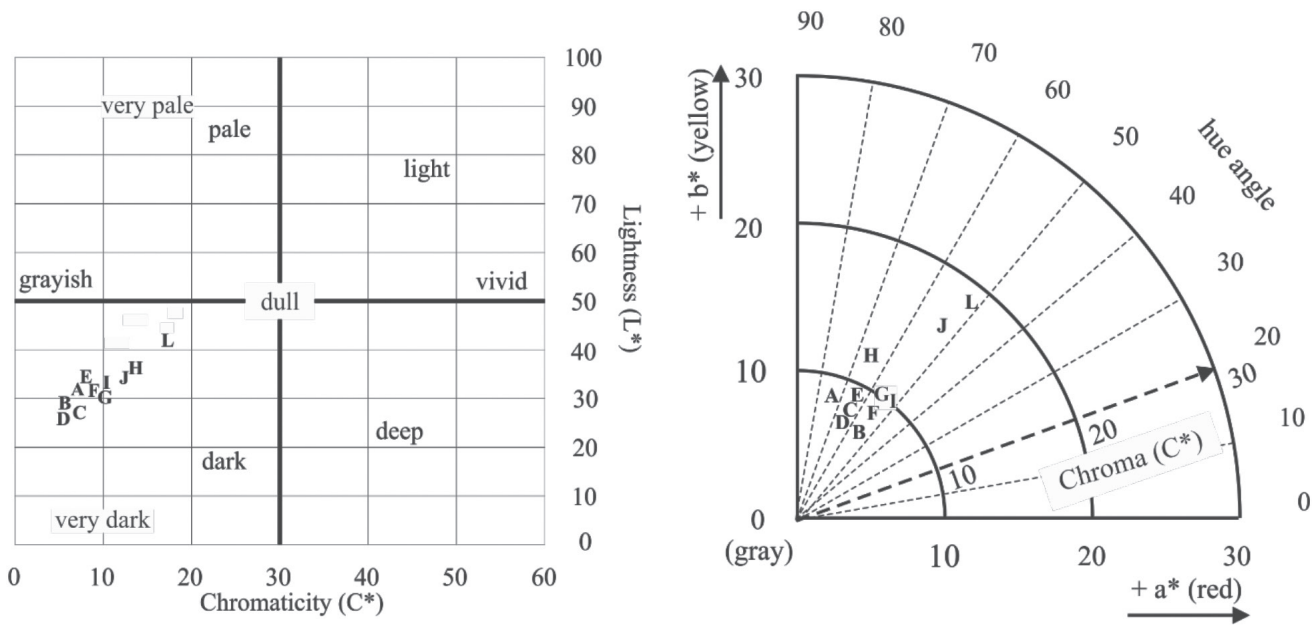

Figure 6. Chromaticity diagram (lightness vs. saturation) of composites (a) and behavior diagram of hue angle of the composites (b). 
Decrease of $h^{*}$ denotes a dislocation from yellow-greenish color to reddish conditions, which is characterized by a decrease from 71,72 to 52,58 when composites A and L are compared. Increase of $C^{*}$ in composites with higher percentage of eucalypt particles is responsible for the increase of intensity and the vivacity of color. Nevertheless, these composites are still in the dark region of the chromaticity diagram (Figure 6). As observed in the chromaticity diagram, all composites presented a very dark color, which increase in opacity with increasing percentages of eucalypt particles.

As observed in this study, use of different agricultural fillers allows the preparation of composites with different visual aspects. Rahman et al. (2010), prepared a rice husk-filled high-density polyethylene composite with reddish brown color, while Butylina et al. (2012) found a pale yellow color in woodpolypropylene composites. Müller et al. (2012) observed a slight increment of yellow tones in PVC/ wood flour composites with increasing amine concentration.

As with the chromaticity diagram (Figure 6a), the diagram in figure 6b - which relates $h^{*}$ and $C^{*}$ clearly showed the color behavior as a function of percentage of particles in the composites. A decrease in percentage of household waste of mate-tea is related to the obtainment of a reddish-brown tone, which is characteristic of eucalypt particles used in this study.

\section{CONCLUSIONS}

Use of particles with different sizes and shapes in the same matrix significantly increased surface roughness. Nevertheless, presence of high surface roughness does not imply the presence of large peaks and valleys.

All composites showed dark color. The possibility to change either the color or the tone of the composite only by adjusting the proportion of filler in the mixture during the composite manufacture is noted.

\section{ACKNOWLEDGMENTS}

We gratefully acknowledge CNPq (National Counsel of Technological and Scientific Development, Brazil) and CAPES (Coordination for the Improvement of Higher Education Personnel, Brazil) for research fellowships, and we thank to Miss Bia Silveira Carneiro for the English revision of the manuscript. 


\section{REFERENCES}

Abu-Sharkh, B.F.; Kahraman, R.; Abbasi, S.H.; Hussein, I.A. 2004. Effect of epolene E-43 as a compatibilizer on the mechanical properties of palm fiber-poly(propylene) composites. Journal of Applied Polymer Science 92 (4):2581-2592.

Akbulut, T.; Hiziroglu, S.; Ayrilmis, N. 2000. Surface absorption, surface roughness, and formaldehyde emission of Turkish medium density fiberboard. Forest Products Journal 50 (6):45-48.

Akgül, M.; Korkut, S.; Camlibel, O.; Candan, Z.; Akbulut, T. 2012. Wettability and surface roughness characteristics of medium density fiberboard panels from rhododendron (Rhododendron ponticum) biomass. Maderas. Ciencia y Tecnología 14 (2):185-193.

Ashori, A.; Nourbakhsh, A. 2010. Reinforced polypropylene composites: Effects of chemical compositions and particle size. Bioresource Technology 101 (7):2515-2519.

Ayrilmis, N. 2011. Effect of fire retardants on surface roughness and wettability of wood plastic composites panels. Bioresources 6 (3): 3178:3187.

Ayrilmis, N.; Benthien, J.T.; Thoemen, H. 2012. Effects of formulation variables on surface properties of wood plastic composites. Composites Part B: Engineering 43 (2):325-331.

Ayrilmis, N.; Kaymakci, A.; 2013. Fast growing biomass as reinforcing filler in thermoplastic composites: Paulownia elongata wood. Industrial Crops and Products 43:457-464.

Binhussaina, M.A.; El-Tonsy, M.M. 2013. Palm leave and plastic waste wood composite for outdoor structures. Construction and Building Materials 47:1431-1435.

Butylina, S.; Hyvärinen, M.; Kärki, T. 2012. Accelerated weathering of wood-polypropylene composites containing minerals. Composites Part A: Applied Science and Manufacturing 43(11):20872094.

Cademartori, P.H.G.D.; Mattos, B.D.; Missio, A.L.; Gatto, D.A. 2014. Color responses of two fast-growing hardwoods to thermal treatment. Materials Research 17(2):487-493.

Cademartori, P.H.G.D.; Schneid, E.; Gatto, D.A.; Stangerlin, D.M.; Beltrame, R. 2013. Thermal modification of Eucalyptus grandis wood: variation of colorimetric parameters. Maderas. Ciencia y tecnología 15 (1):57-64.

Clemons, C. 2002. Wood-Plastic Composites in the United States. The interfacing of two industries. Forest Product Journal 52 (6):10-18.

Darabi, P.; Gril, J.; Thevenon, M.F.; Karimi, A.N.; Azadfalah, N. 2012. Evaluation of high density polyethylene composite filled with bagasse after accelerated weathering followed by biodegradation. BioResources 7 (4):5258-5267.

Dubey, M.K.; Pang, S.; Walker, J. 2012. Changes in chemistry, color, dimensional stability and fungal resistance of Pinus radiata D. Don wood with oil heat-treatment. Holzforschung 66:49-57.

Haque, M.M.; Hasan, M.; Islam, M.S.; Ali, M.E. 2009. Physico-mechanical properties of chemically treated palm and coir fiber reinforced polypropylene composites. Bioresources Technology 100 (20):4903-4906.

Jarusombuti, S.; Ayrilmis, N. 2011. Surface characteristics and overlaying properties of flat-pressed wood plastic composites. European Journal of Wood and Wood Products 69 (3):375-382. 
Jeamtrakull, S.; Kositchaiyong, A.; Markpin,T.; Rosarpitak, V.; Sombatsompop, N. 2012. Effects of wood constituents and content, and glass fiber reinforcement on wear behavior of wood/PVC composites. Composites Part B: Engineering 43(7):2721-2729.

Kaymakci, A.; Ayrilmis, N.; Gulec, T. 2013. Surface properties and hardness of polypropilene composites filled with sunflower stalk flour. BioResources 8 (1):592-602.

Kazayawoko, M.; Balatinecz, J.J.; Matuana, L.M. 1999. Surface modification and adhesion mechanisms in wood fiber-polypropylene composites. Journal of Materials Science. 34(24):6189-6199.

Magalhães, W.L.E.; Pianaro, S.A.; Granado, C.J.F.; Satyanarayana, K.G. 2013. Preparation and characterization of polypropylene/heart-of-peach palm sheath composite. Journal of Applied Polymer Science 127 (2):1285-1294.

Mengeloğlu, F.; Karakuş, K. 2008. Some properties of Eucalyptus wood flour filled recycled high density polyethylene polymer-composites. Turkish Journal of Agriculture \& Forestry 32 (6):537-546.

Müller, M.; Militz, H.; Krause, A. 2012. Thermal degradation of ethanolamine treated poly(vinyl chloride)/wood flour composites. Polymer Degradation and Stability 97(2):166-69.

Ozdemir, T.; Hiziroglu, S.; Malkocoglu, A. 2009. Influence of relative humidity on surface quality and adhesion strength of coated medium density fiberboard (MDF) panels. Materials \& Design 30 (7):2543-2546.

Pagliosa, C.M.; De Simas, K.N.; Amboni, R.D.M.C.; Murakami, A.N.N.; Petkowicz, C.L.O.; Medeiros, J.D.D.; Rodrigues, A.C.; Amante, E.R. 2010. Characterization of the bark from residues from mate tree harvesting (Ilex paraguariensis St. Hil.). Industrial Crops and Products 32(3):428-433.

Rahman, M.D.; Islam, M.D.N.; Huque, M.D.M.; Hamdan, S.; Ahmed, A.S. 2010. Effect of chemical treatment on rice husk (RH) reinforced polyethylene (PE) composites. BioResources 5(2):854869.

Tserki, V.; Matzinos, P.; Kokkou, S.; Panayiotou, C. 2005. Novel biodegradable composites based on treated lignocellulosic waste flour as filler. Part I. Surface chemical modification and characterization of waste flour. Composites Part A: Applied Science and Manufacturing 36 (7):965-974. 